\title{
A REVISED LIST OF THE HERPETOLOGICAL FAUNA OF CULEBRA ISLAND
}

\author{
Chapman Grant, Major, U. S. Army
}

Schmidt, 1928 gives the following nine amphibians and reptiles as comprising the Culebra Island herpetological fauna. After each name is added the number of specimens collected on the present trip.

1. Leptodactylus albilabris (Gunther) -._-_-_-_-_-_-_ 4

2. Eleutherodactylus antillensis (R. \& L.) -.......-.-- 1

3. Anolis cristatellus (see below)

4. Anolis stratulus Cope-_-_-_-_-_-_-_-_---- 16

5. Anolis pulchellus (D. \& B.) -

6. Amieva exsul Cope-_-_-_-_-_-_ 20

7. Mabuya sloanii (see below) -_._-_-_-_-_-_-_ 0

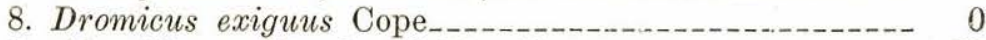

9. Alsophis antillensis (Schlegel)-_-_-_-_-_-_--- 28

The following species were taken and are added to the above list:

1. Sphaerodactylus danforthi $\mathrm{sp}$. nov. $1^{\text {" }}$ _._._......... 180

2. Anolis roosevelti $\mathrm{sp}$. nov. $2^{\text {* }}$

3. Typhlops jamaicensis (Shaw) _._-_._-_._-_._- 10

Of the original list I have changed the following:

1. Mabuya sloanii (Daudin) to M. semitaeniatus (Wiegmann) $3^{\text {" }}$

2. Anolis cristatellus D.\&B. to Anolis cristatellus wileyi sub sp. nov. 4 (3)

This makes a total of 12 species now known to inhabit Culebra Island.

At the time of my visit, April 15-24, 1931, the island was extremely dry which accounts for the poor showing of Salentia and probably for the lack of Dromicus exiguus Cope which may have been aestivating.

I found Anolis cristatellus wileyi the only common reptile with Sphaerodactylus danforthi next in number. Amieva exsul was not common on Culebra, not seen on Louis Pena key, but was the most abundant form on Culebrita. Anolis pulchellus (D. \& B.), Anolis stratulus Cope and Amieva exsul Cope showed no variation from their Porto Rican relatives.

$1^{*}, 2^{*}, 3^{*}$ and $4^{*}$ deseribed on pages $205,219,217$ and 220 respectively in this number. 